\title{
Scarcity Amidst Plenty: Lower Himalayan Cities Struggling for Water Security
}

\author{
Hemant Ojha ${ }^{1,2} \mathbb{D}$, Kaustuv Raj Neupane ${ }^{3, *} \mathbb{C}$, Chandra Lal Pandey ${ }^{3,4}$, Vishal Singh ${ }^{5}$, \\ Roshan Bajracharya ${ }^{3}$ and Ngamindra Dahal ${ }^{3}$ (D) \\ 1 Centre for Deliberative Democracy and Global Governance, University of Canberra, Canberra, ACT 2610, \\ Australia; hemant.ojha@canberra.edu.au \\ 2 Institute for Studies and Development Worldwide (IFSD), Sydney, NSW 2140, Australia \\ 3 Southasia Institute of Advanced Studies (SIAS), Kathmandu 44600, Nepal; \\ chandra.pandey@ku.edu.np (C.L.P.); roshan@sias-southasia.org (R.B.); ngamindra@sias-southasia.org (N.D.) \\ 4 School of Arts, Kathmandu University, Lalitpur 44700, Nepal \\ 5 Centre for Ecology Development and Research, Dehradun 248001, India; vishal@cedarhimalaya.org \\ * Correspondence: kaustuv@sias-southasia.org; Tel.: +977-1-4469801
}

Received: 21 October 2019; Accepted: 13 December 2019; Published: 19 February 2020

\begin{abstract}
In recent years, growing water insecurity in the Himalayan region has attracted new scientific research and fresh attention on policy. In this paper, we synthesize field research evidence from a sample of five Himalayan cities-three in Nepal and two in the western Indian Himalayas-on various forms of water insecurity and cities' responses to such challenges. We gathered evidence from a field research conducted in these cities between 2014 and 2018. We show how different types of Himalayan towns (mainly hilltop, foot hill, river side, touristic, and regional trading hub) are struggling to secure water for their residents and tourists, as well as for the wider urban economy. We found that even though the region receives significant amounts of precipitation in the form of snow and rainfall, it is facing increasing levels of water insecurity. Four of the five towns we studied are struggling to develop well-performing local institutions to manage water supply. Worse still, none of the cities have a robust system of water planning and governance to tackle the water challenges emerging from rapid urbanization and climate change. In the absence of a coordinated water planning agency, a complex mix of government, community, and private systems of water supply has emerged in the Himalayan towns across both Nepal and India. There is clearly a need for strengthening local governance capacity as well as down-scaling climate science to inform water planning at the city level.
\end{abstract}

Keywords: water security; urban water; climate change; Himalayas; water planning; water access and equity

\section{Introduction}

Despite being endowed with the third largest ice mass after the two polar regions, and despite receiving annual precipitation level higher than the global average (except some desert segments in the western Himalaya, the region overall receives an average of $3000 \mathrm{~mm}$ rainfall, as against the global average of $1000 \mathrm{~mm}$ ) [1,2] the lower Himalayan region [3] and its hydrological downstream have become a water crisis hotspot under changing climate and persistent governance issues (The $\mathrm{HKH}$ has a total of 54,252 glaciers occupying $60,054 \mathrm{~km}^{2}$ and an estimated ice reserve of $6127 \mathrm{~km}^{3}$ [3]). An emerging body of studies have shown that there is an escalating problem of water insecurity in the region [4], exacerbated by both demand and supply side problems [5]. Growing water insecurity is indeed a global challenge, under rapid rate urbanization, climate change, and continuing issues 
around water governance [6]. On the demand side of the water challenge, towns and urban areas are expanding rapidly [7], and hosting ever-growing urban populations and industries. As approximately $66 \%$ of the world population will be living in urban areas by 2050 , cities need to prepare for another 2.5 billion people by mid-century, with $90 \%$ of this growth happening in Asia and Africa [8]. On the supply side, round-the-year supply of water is disrupted in the Himalayas and downstream as a result of climate change, which is affecting the region severely [9]. In a study of 482 largest cities of the world using a predictive model, it is estimated that almost $46.6 \%$ of cities may experience a surface-water deficit by 2050 [6]. Making the situation worse in the Himalaya is its geography—as human settlements (along the $2500 \mathrm{~km}$ long Himalayan range) are not always situated at the bottom of the valley with a plentiful supply of water, but on water-scarce hilltops. With growing ecotourism in the urbanizing Himalayas, hilltop towns are facing increasing water demand. Amidst all of this, water insecurity in Himalayan Asia has also been recognized as an issue of regional cooperation [10].

Water security as a concept became popular since the 1990s, and the definitions have widened from the initial focus on physical quantity of water to more interdisciplinary and socio-natural approaches. During this period, the concept has taken on diverse meanings according to various contexts and perspectives [11]. Multiple definitions have been advanced by several international organizations [11-14]. There have even been attempts to define indicators of water security, covering diverse dimensions, such as welfare, access, risks, and sustainability [15]. Global Water Partnership defines water security as one in which 'there is enough water for social and economic development and ecosystems' [16]. The notion of water security is also embracing the need to articulate water use as a human right, especially under increasing commoditization [17] and the increasing involvement of the private sector [18]. For the purpose of this paper, we define water security as access to water by the people within an institutional arrangement, which has the capacity to overcome technical and environmental barriers to water use and management. We also consider water security as a normative concept requiring transitions in governance and socio-technical systems [19].

While Himalayan-wide studies highlight general trends of water flow under the changing climate, there is a notable lack of studies of city scale water insecurity situations and responses made by the city level institutions in the Himalayan towns. Considering this gap, we conducted action research with five caste study towns to understand town-specific water insecurity challenges, and then also to test collaborative approaches to tackle these challenges. Our research captured in this paper was guided by the question: What forms of water insecurity are the lower Himalayan cities experiencing and how are these cities responding to the challenges? Our aim was not to test a specific theoretical model of water security but to identify and assess the actual water insecurity situations and city level responses to tackle the challenges. Our point of departure was that cities' responses to water insecurity could involve investment of resources, formulating plans, creating or adapting institutional arrangements, adopting a new technology in water management, or even reconfiguration of roles among actors (See Figure 1 for the elements we cover in this paper). Water security as an outcome should also capture broad dimension of access, equity, and resilience in relation to climate impact. In view of the limited studies of urban water systems in the region, our focus was not to present a comparative analysis of the case studies but to showcase the five different city level stories of water insecurity, and the cities' struggle in overcoming it. The main contribution of this paper is to show how different types of Himalayan towns (hilltop, foot hill, river side, water stressed, touristic, and trading hub) are struggling to secure water for their residents, tourists, and the infrastructure, despite the region receiving significant amounts of annual precipitation. We also identify key themes and issues in relation to urban water insecurity in the Himalayas. Other aspects of analysis of water insecurity challenges from these case studies have been reported in other papers which were the outcomes of the research project on which this paper is based [20-23]. 


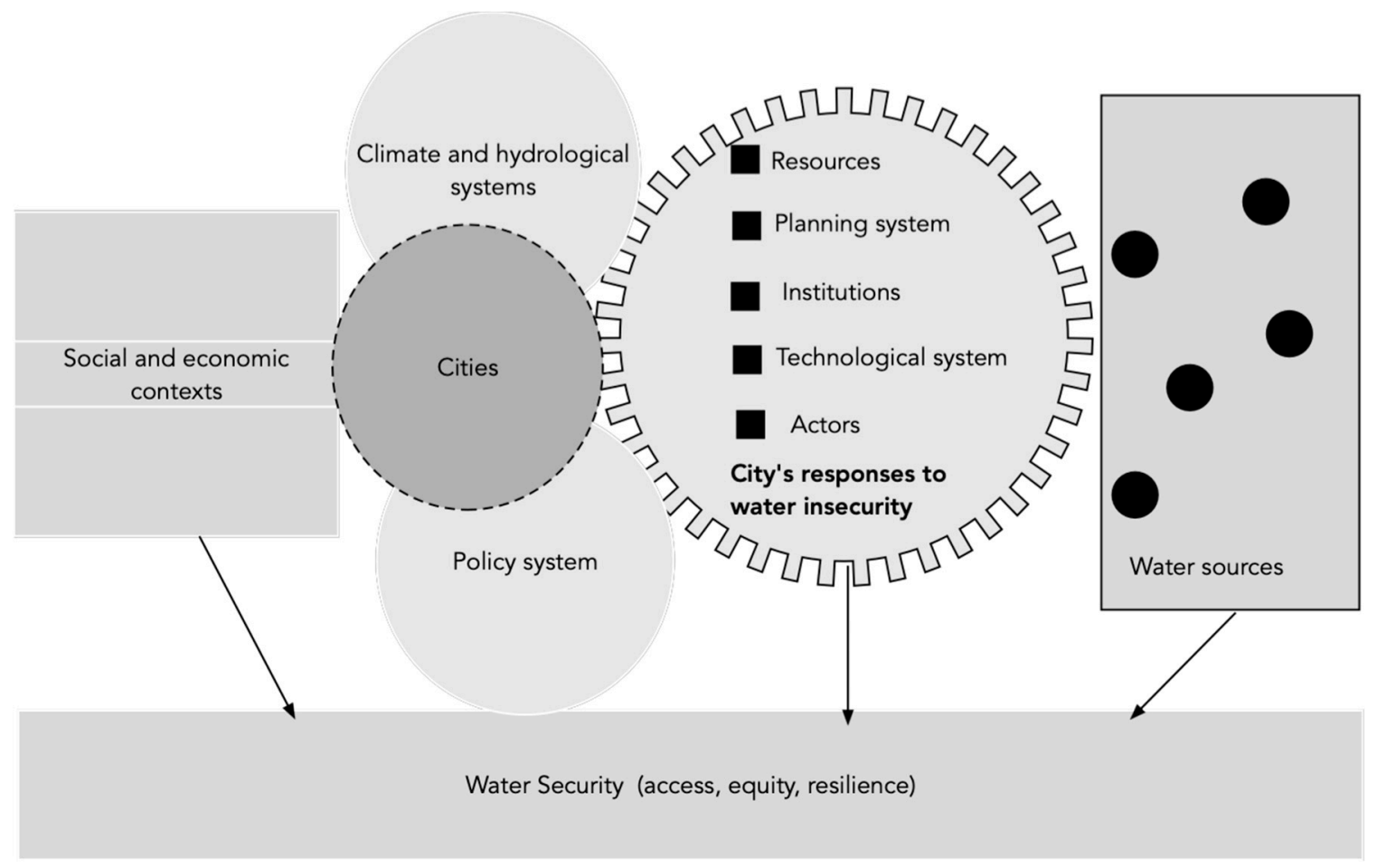

Figure 1. A Conceptual overview of cities' struggle for access to water.

\section{Overview of Case Studies and Research Methods}

The region where we conducted case studies stretches from the eastern Himalayas in Nepal to the Western Himalaya in the Indian state of Uttarakhand. A city has been taken as the unit of study to understand water insecurity. The cities in the case study represent diverse categories found in the Himalayan region-hilltop touristic cities (Dhulikhel and Mussoorie), foothills commercial cities (Bidur, Dharan, and Haldwani) (See Figure 2 for the locations of the case study cities). The region is internally diverse, both geographically and in terms of social and economic situations, and our five case studies in no way provide a full picture of the region. Small and medium, mountainous and foothill cities are common in the Himalayan region of India and Nepal. Hill top towns are popular tourist destinations, whereas, foothill towns are major trading gateways for the mountain people. As highways are being constructed or expanded across river valleys, there is an increasing trend of hilltop communities moving down to the new urbanizing settlements in the valley floor, as found in Bidur, Dharan, and Haldwani. Despite such diversity, the selected cases do provide fairly representative picture of water insecurity in the region, as well as illustrating the diverse ways in which cities respond to the challenges of water insecurity.

Water supply has become a major agenda of development in the region. In Nepal, the piped water supply has reached only about $40 \%$ of the country's households, and the average water consumption per capita is dismally low, at only about 35 to 55 Liters per Capita per Day (LPCD), compared to WHO standards of 112 to 150 LPCD [24]. In Uttarakhand, approximately, 78\% of urban households are connected to the piped water system, but the duration of water supply varies between three to four hours daily [25]. Besides quantity, the quality of water has become an even more serious issue, but with much less research and policy attention [26]. The two countries also present a long history of community and state institutions in water management. 
Each town has a unique history of water management, with a multiplicity of institutions involved in managing or regulating different aspects of the water supply system and water sources conservation and management (See Table 1 for an overview of the five cities' water supply situation). Two of the case study towns-Mussoorie in India and Dhulikhel in Nepal—both receive a significant number of floating populations of tourists, especially Mussoorie. These hilltop towns receive limited supply of water from their upstream sources, forcing Mussoorie to pump up water from the lower elevations while Dhulikhel taps water from sources that are $12 \mathrm{~km}$ away. Three other towns-Haldwani in India and Dharan and Bidur in Nepal—are located at the foot of the lower Himalayas, and are major economic hubs in the respective regions. In these cities, water demand is not driven by floating population of tourists, but by consistently growing economic and industrial activities. In terms of physical access to water, Dharan is adjacent to a big perennial river Koshi (and its tributary Tamor), and as yet, the city's water supply system has not sourced water from this river. Haldwani is adjacent to a small river (Gaula), but not with adequate water to meet the increasing demand. Bidur is situated at the bank of a perennial snow-fed river (Trishuli), but without a successful installed pumping facility.

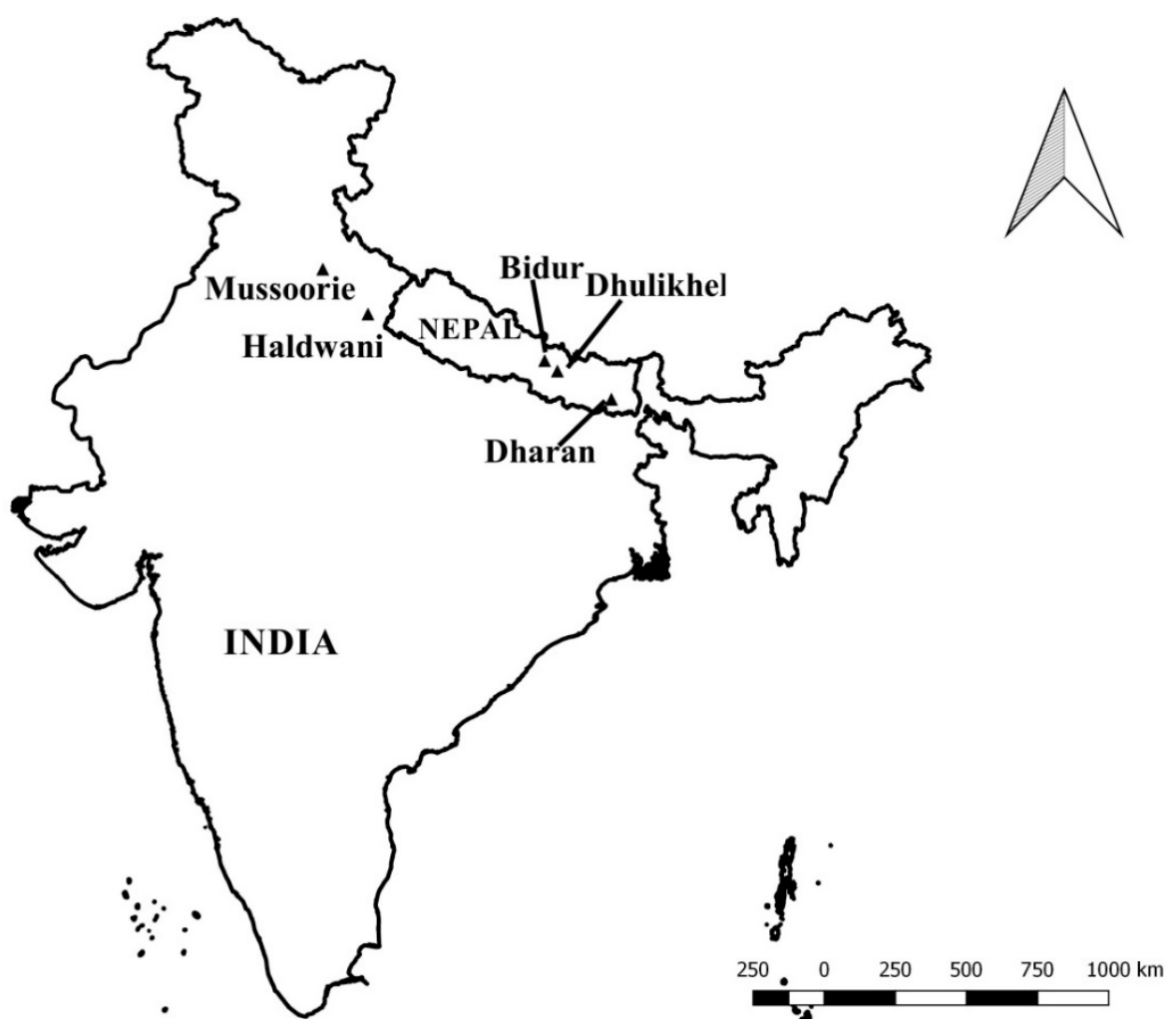

Figure 2. Location of the five case study cities in the Himalayas. 
Table 1. Comparative overview of the five cities.

\begin{tabular}{|c|c|c|c|c|c|c|c|c|}
\hline City & Population & $\begin{array}{c}\text { Elevation } \\
\text { (masl)/Location of City }\end{array}$ & $\begin{array}{l}\text { Population } \\
\text { Growth Rate }\end{array}$ & $\begin{array}{c}\text { Current } \\
\text { Water Demand }\end{array}$ & Current Water Supply & Sources of Water & $\begin{array}{l}\text { Responsible Agency for } \\
\text { Water Supply }\end{array}$ & $\begin{array}{l}\text { Year-When the Key Water } \\
\text { Project Commenced }\end{array}$ \\
\hline Bidur, Nuwakot, Nepal & 22,277 & Foot hill (580) & 1.25 & 3.30 & NA & $\begin{array}{l}\text { Trishuli river, Falkhu River, } \\
\text { Nalagaun Spring and } \\
\text { multiple local springs }\end{array}$ & $\begin{array}{l}\text { Bidur drinking water users } \\
\text { committee (BDWUC), } \\
\text { and more than } 30 \text { registered } \\
\text { water users committee, } \\
\text { private wells in river banks }\end{array}$ & Registered on 23 February 1996 \\
\hline Dharan, Sunsari, Nepal & 136,816 & Foot hill (119 to-1778) & $+2.11 \%$ & 14.41 MLD & $\begin{array}{l}\text { Wet season: } 13 \text { MLD; } \\
\text { Dry season 10.9 MLD }\end{array}$ & $\begin{array}{l}\text { Shardu Watershed, ground } \\
\text { water through deep tube } \\
\text { well, local streams } \\
\text { and springs }\end{array}$ & $\begin{array}{l}\text { Nepal Water Supply } \\
\text { Corporation, and local } \\
\text { water users committees }\end{array}$ & $\begin{array}{l}\text { First piped water supply in } \\
1961 \text { (by British Army) and } \\
\text { NWSC started management } \\
\text { since } 1982\end{array}$ \\
\hline Dhulikhel, Kavre, Nepal & 21,190 & Hill top (1550) & 1.60 & 23.1 MLD & 13.8 MLD & $\begin{array}{l}\text { Rosi river, multiple springs } \\
\text { in Dhulikhel forest, } \\
\text { and ground water }\end{array}$ & $\begin{array}{l}\text { Dhulikhel drinking water } \\
\text { users committee (DDWUC) } \\
\text { and other few water } \\
\text { users committee }\end{array}$ & $\begin{array}{l}\text { DDWUC started } 1987 \text { and was } \\
\text { completed in } 1991\end{array}$ \\
\hline $\begin{array}{l}\text { Haldwani, } \\
\text { Uttarakhanda, India }\end{array}$ & 156,078 & Foot Hill (554) & $\begin{array}{c}+30.1 \\
(2001-2011)\end{array}$ & 36.4 MLD & 26.67 MLD & $\begin{array}{l}\text { Gaula River, surface water } \\
\text { flow from Sheetlahat, } \\
\text { and sub-surface water from } \\
\text { tube wells }\end{array}$ & Jal Sansthan/Jal Nigam & $\begin{array}{l}\text { Introduced in } 1948 \text { through } \\
\text { Sheetlahat spring }\end{array}$ \\
\hline $\begin{array}{l}\text { Mussoorie, } \\
\text { Uttarakhanda, India }\end{array}$ & 30,118 & Hill top (1880) & $15.5(2001-2011)$ & $\begin{array}{c}\text { 14.4 MLD (peak } \\
\text { tourist season) }\end{array}$ & 7.67 MLD & 23 springs around the town & Jal Sansthan/Jal Nigam & $\begin{array}{l}\text { Gravitation and stream water } \\
\text { pumping since 1909; last } \\
\text { pumping installed in } 2003\end{array}$ \\
\hline
\end{tabular}

Source: Central Bureau of Statistics, Nepal and various other sources located by authors. 
The information and evidence underpinning this paper is based on a field research conducted from 2014 to 2018. Data were collected through a range of qualitative and quantitative techniques. The filed research started with inception meetings with city level officials and community leaders, to explain the purpose of the research and seek their cooperation (Bidur, Dhulikhel and Mussoorie in 2014; Dharan and Haldwani in 2016). In the next step, we conducted geographic mapping of water sources and key informant interviews to understand and document the history and current institutional arrangements for water management in each city (Bidur, Dhulikhel and Mussoorie in 2015; Dharan and Haldwani in 2017). In the third stage, we conducted focus group discussions with various marginalized groups in relation to water access-such as squatter groups, water strained settlements, and disadvantaged women's groups. We then began preliminary data analysis and initiated some participatory research activities, such as co-organising water forums with the municipalities (Bidur in 2015; Dharan, Dhulikhel, Haldwani, and Mussoorie in 2017-2018). Gathering of grey literature and archival evidence continued throughout the research period. We broadly followed grounded theory techniques and formulated unique analytical stories of the five cases. We structured the case story around three themes: (a) the nature and extent of water insecurity cities are experiencing, (b) key interventions and responses, and (c) key messages that we can derive from the story. In the second stage of the analysis, we created two main codes (categories) to analyze the information across the five cases-(a) water insecurity and (b) responses of the cities. We then pooled all empirical findings and juxtaposed these between the two categories, with a view to developing a synthesized view of water insecurity and city level responses across the case studies (which is presented in Section 8).

\section{Bidur: Plenty of Water but Limited Access}

The town of Bidur is located near the confluence of Trishuli and Tadi rivers in the central Nepal Himalaya, nearly $40 \mathrm{~km}$ to the northwest of the capital city of Kathmandu. Bidur's 30 thousand residents are struggling for water access for domestic and public use [27], despite being located at the bank of the two perennial rivers (and at an elevation as low as $470 \mathrm{~m}$ ), due to Bidur's limited institutional capacity. The town relies on water springs and small streams in the upstream areas. The city's water struggle is on the rise, as the urban settlements are expanding rapidly and communities in the upstream areas are intensifying their claims over the water sources for local use. According to the file record by the municipality in December 2013, 185 building maps were applied to the municipality office to build. Among them, 164 were approved. Similar cases were found in previous years too. The town's water demand is growing continuously because of the growing economic activity linked to the hydropower development projects further north of the town. More recently, the town has been connected to a new highway which links Nepal with a major border point in Tibet, China.

In 1995, the town witnessed its first municipal level water supply system development project from the Government of Nepal. After the completion of the project, the system has been handed over to Bidur Water Users Supply Committee (BWUSC), which is a community institution of over 2000 households located in the town. Its water supply covers nearly $40 \%$ of the Bidur residents, although the actual supply of water is intermittent and limited. BWUSC manages water tapped from a small river, some $10 \mathrm{~km}$ north of the town, towards the higher range mountains of the Himalaya. In addition, water is also tapped from other smaller spring sources, with pipelines installed to collect water into its reservoirs and then to distribute to individual households, while also allocating some water to public taps for limited hours in a day (See Figure 3, a photo of a community tank with a number of pipes connected for local distribution to multiple households). In 2016, when we conducted our field work, the water supply level was far below the demand for water, and building and operating an integrated drinking water supply system proved incredibly challenging despite decades of effort. 


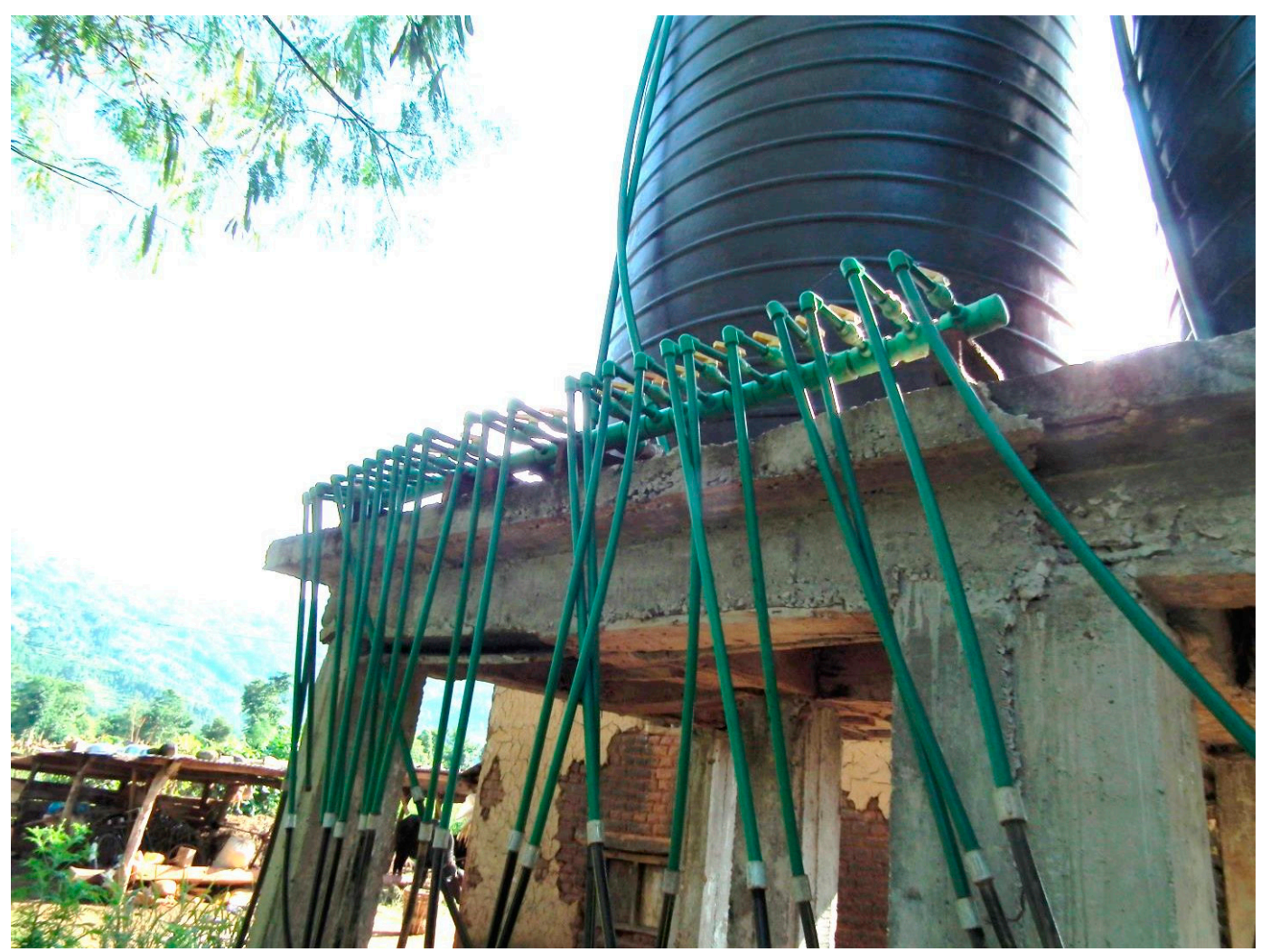

Figure 3. Photo of a community managed water supply tank (with a number of pipes connected to it for distribution to local households).

As $60 \%$ of Bidur residents were left out of the BWUSC supply system, smaller and community-led water supply systems emerged in the town, especially in the southern suburban areas. These community led projects emerged during 1990-2000 in Nepal when the state was paralyzed by the nationwide conflict, leaving the town without an elected local government. In the absence of city scale coordinated water supply system, Bidur Municipality has seen over three dozen water users committees, each of which taps one or more spring water sources from the neighboring mountains. These groups include as small as two households to as large as the one with 400 households, that tap water from a specific spring source. Growing demands for new water connections through the old supply lines have put huge pressures on the existing systems.

In the absence of institutional arrangements to coordinate the management and supply of waters at the town level, and also between the town and the neighboring rural areas, cases of water access conflicts are on the rise. Conflicts over water sources are intensifying between drinking water user groups and small and poor farmers, exacerbated by growing demands for drinking and water use from settlements further afield [28]. Another source of conflicts has been the competing priority between municipal supply and rural irrigation. In a recent interaction program (Project Inception meeting held on Bidur 9 November 2014) held in Bidur Municipality, a poor farmer from an upstream village said in his trembling voice "Our water has been taken away (for drinking), leaving behind no water for us to save our seeds in my field even so close to the water source". Another issue is that the local debate on water access is dominated by quantity, and there is very limited attention to water quality issues. Quality issues are no less serious than the quantity of supply, as there are no treatment facilities in the system.

Improvement in Bidur's municipal supply is not possible without expanding the system to tap water from the bigger and perennial river Trishuli. Recently, the Asian Development Bank (ADB) and the Government of Nepal endorsed a proposal for Bidur Municipality to build a new intake system 
and pipelines. In response to the demand from local political leaders, the government invited ADB to support the upgrading of BWUSC supply system. Under this system, the Government of Nepal will provide $70 \%$ of the budget (financed through $\mathrm{ADB}$ ), while $25 \%$ is raised as the loan from Town Development Fund, and the remaining 5\% contributed by the local water user group. However, considering Nuwakot district as one of the most affected by the 2015 earthquake, the fund required to be paid by the local water user committee was provided as a grant by the Government. ADB is providing a mix of loans and grants on the condition that Bidur residents pay their share of the project cost when the project starts operation. This requires increasing tariff rates and forming a strong functional management team. This project construction work is in progress and BWUC has formed a municipal level Grievance Resolution Committee to address community complaints about the project [29].

In terms of the key message, Bidur's ongoing water access struggle presents a challenging situation facing a small town in the floor of a river valley in the lower Himalayas, where the state led and internationally supported water supply development project has been unable to cater to the water needs of the growing number of town residents, despite there being plenty of water in the locality. As a result, numerous community-led small water supply groups emerged and are functioning. These groups are also experiencing conflicts and issues related to water quality, quantity, and delivery efficiency. While small and community-led efforts filled the institutional gap and have demonstrated some merit, a crucial question arises as to how more coordinated water supply planning could occur in the town, in cooperation with the water supplying neighboring localities in the rural upstream areas. This means water supply system is required to harnesses the institutional power of both the government and the local community, while also considering the longer term trends of urbanization and the growing impact of climate change. Central to Bidur's struggle for water security is the lack of a functioning institutional arrangement and a city level water planning that can monitor current and future scenarios of water demand and supply, as well as advise the local and higher level government on actions to be taken.

\section{Dharan: Multiple Sources and Diverse Water Supply Systems, but Not Enough Water}

Situated at the foot of the eastern Nepal Himalaya some $300 \mathrm{~km}$ east of Kathmandu, and with approximately 200,000 residents, Dharan is a major trading town in the eastern region of Nepal. Geographically, it is located in the Bhabar region, which is the first strip of flat land after the range of mountains end onto the vast stretch of South Asia's Gangetic plains, comprising Nepal's Terai and much of the Indian states of Uttar Pradesh, Bihar, and West Bengal. As such, Dharan geography is characterized by a low groundwater level. The city has two ephemeral streams on two sides, with no perennial rivers flowing close to this town (unlike Bidur). The nearest perennial river Koshi flows $14 \mathrm{~km}$ west of the city and another river Tamor is $25 \mathrm{~km}$ away. While these large rivers flow downstream with vast amount of water volume, Dharan city struggles to meet the basic water requirements of its citizens and their businesses. The city population is growing at a rate of $4.5 \%$ annually, as migrants from the neighboring hill districts settle there. It is facing acute water scarcity, with the current supply level of 15 Million Liters per Day (MLD) against the demand for 30 MLD. This is mainly because it is located at the foot of a low hill with limited surface runoff from the catchment areas [23,30]. The city water supply system consists of tapped water from multiple sources-mainly upstream catchment flows and groundwater abstraction [30]. Community leaders are of the view that Dharan is lagging in its tourism infrastructure due to the chronic water stress, despite having huge potential. "Dharan does not have a single-starred hotel despite being a regional trading hub and receiving so much remittance every year. This is simply because there is not enough water here," said a local political leader (Field note 2016). Many of its residents are required to spend hours to attain water or use untreated and polluted water from local springs and rivulets.

The city's history of water supply development dates back to 1961 when British Army Engineers constructed the first piped water supply system by tapping water from two ephemeral rivulets-Sardu and Khardu—flowing down right next to the city. The system was later managed by Dharan Municipality, 
before it was finally handed over to the government-owned Nepal Water Supply Corporation (NWSC) in 1982. NWSC expanded its system in the late 1980s by extracting groundwater (for details of water sources, see Figure 4), but with the continuous increase in demand, the supply has been far from adequate. Currently, the Sardu and Khardu system meet only one-third of the town's water need (NWSC collects 12 to 13 MLD in wet season and 4 to 4.5 MLD in dry season from both Sardu and Khardu Kholas [30], and the supply volume further diminishes during the dry season. Although about $98 \%$ of Dharan households are connected to the water supply grid, the supply is confined to rainy season with the intermittent supply of largely unsafe water [23]. Worse still, the supply hours are reduced drastically during the dry season with most of the areas receiving water for only two hours daily. Moreover, not every suburb receives an equal amount of water. The areas at the far end of the distribution system receive much less supply. In some cases, public agencies have filled water access gap in the marginal areas by providing public taps (For example, NWSC and the Municipality have provided some levels of service to the poor). One of the four priority areas identified in the city water forum meeting held on 3 August 2016 was Squatter's limited access to water services.

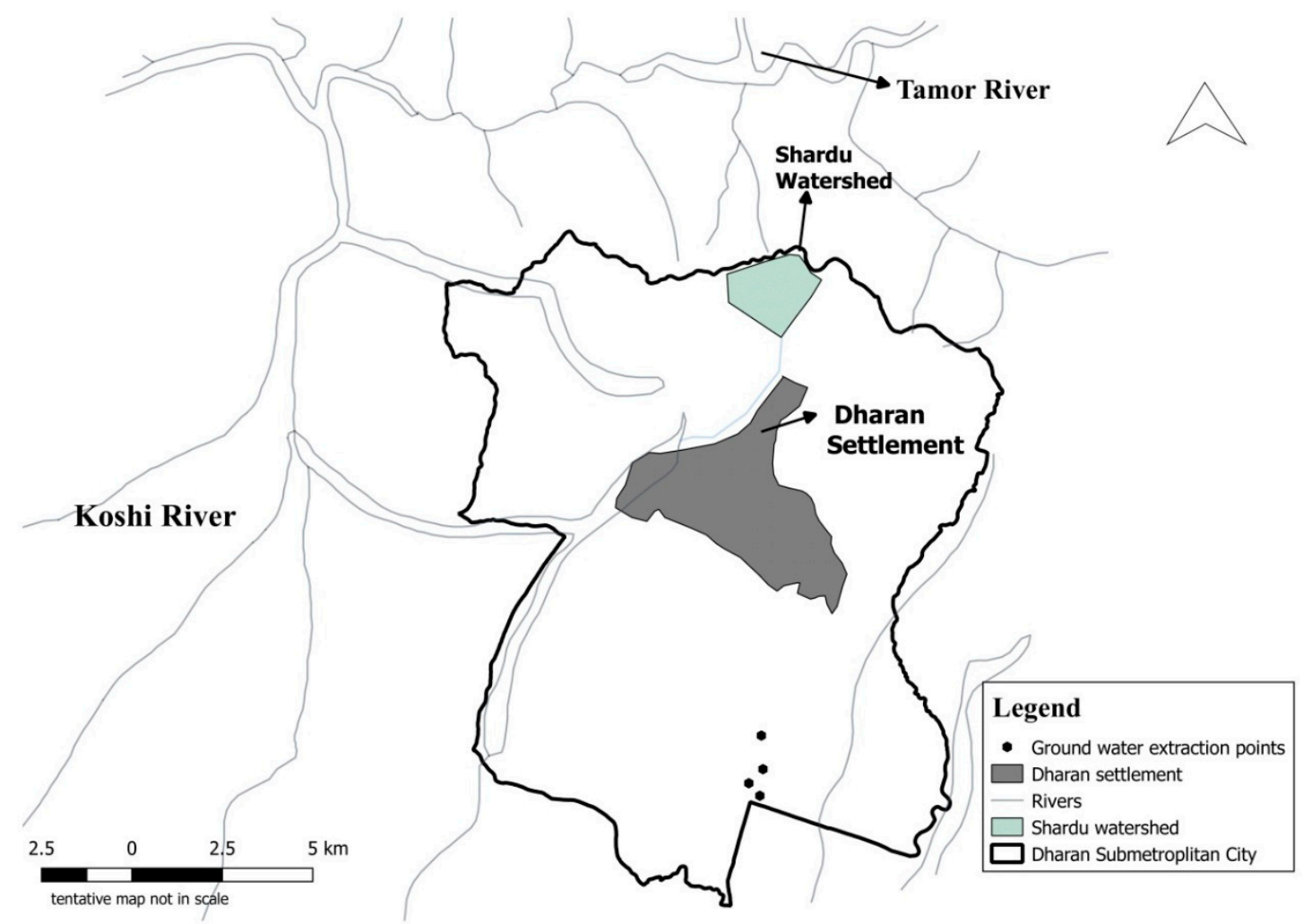

Figure 4. Dharan city map showing different water systems and also showing Koshi and Tamor river in the background.

To augment the supply, a groundwater source was added to the surface water system, abstracting groundwater from a forest area a few kilometers south of the town using extra energy to pump up water from lower elevation zones on a daily basis. These wells are $200 \mathrm{~m}$ deep, which is much deeper than the normal household wells. This could be a potential flashpoint for future conflict when the water table becomes inaccessible by the shallow tube well installed by the city residents. In addition, small spring sources such as Kali khola, Tirke, Teendhare, Devi khola have been tapped by local community groups separately and on their own. These sources are unreliable and seasonal, and the percentage of the population served by these sources is also small. To meet the city's unmet water demand, private tankers based at another town further down also occasionally supply water to consumers especially in the dry season. More recently, several houses and institutions have built rainwater harvesting (RWH) 
units, but the water collected from RWH is not to recharge groundwater nor for domestic purposes, but rather poured into the storm-water.

As in the case of Bidur, ADB has supported the municipality to implement a drinking water project with an objective to augment Dharan's water supply. The project considered multiple source options before finally selecting the groundwater. The first option was to conserve water in the two watersheds of the existing water supply system, but it was dropped as additional water was not available. Another option was to bring water from Tamor river via a tunnel, but it was rejected due to its high cost. Still, another option was building an over-ground diversion from the Koshi River, which was found too costly. The only option left was to pump up more groundwater by installing additional tube wells in the forest area beneath the town-this is what is currently being done as part of the ADB-supported project. The ground water option became promising, although integrated consideration of underground, surface, upstream, and downstream sources is lacking. However, some have raised questions about the sustainability of the underground system, and the ADB project, which has set a project life of 30 years, has acknowledged this issue.

A key message from Dharan is that, despite multiple sources and projects, water supply is dismally low compared to demand, mainly because of the lack of coordinated and planned management of the system to match the growing demand. The story of Dharan shows how a rapidly growing and middle size town in Nepal, located at the foot of the lower Himalaya (Mahabharat hills) with unfeasible ground water right beneath the town, and also having only small ephemeral rivulets close to it, has been struggling to manage the supply of water for its residents and industry. Tamor and Koshi, the perennial rivers have an abundance of water flow in the surrounding areas of Dharan. However, there has been no institutional capacity to obtain water due to the weak governance in the wake of political transition and a lack of elected local government for almost two decades prior to 2017. Another important message is that institutional ambiguity cripples local capacity to manage water effectively. The centrally managed state water institutions (NWSC) took over the water supply project management role. In 2017, the elections of local government bodies took place and newly elected officials assumed roles in the Municipality. The Municipality now claims its authority to manage the city's water supply system, leading to conflicting and competing roles and interests of NWSC, Dharan Municipality and a newly formed Water Board of Dharan. The lack of institutional capacity and coordination among multiple agencies has hampered the city's ability to plan water supply and management, considering all available sources, despite access to some international technical assistance.

\section{Dhulikhel: Insufficient Supply, but Capacity to Secure Water?}

Unlike Bidur and Dharan, Dhulikhel is a hilltop town in the Nepal Himalaya, $35 \mathrm{~km}$ east of Kathmandu. With a population of 66,405 [31] and nearly the same number of floating population of tourists and students, the town's demand for water is rising. Over the past three decades, it has been able to overcome serious water scarcity through continuous efforts, but recent scarcity level has come to a very challenging point. More than a dozen hotels, a leading university campus (Kathmandu University) of Nepal, and the nationally reputed Dhulikhel hospital all add to the ever increasing demand for water for purposes beyond 'drinking'. In the summer of 2018, we found a huge gap between the supply and demand of water in the town. The supply of water is 13.8 MLD, whereas, the demand is 23.1 MLD [23]. Although it has installed a piped connection to $48 \%$ of households, this system does not supply enough water to the majority of the residents [24]. In terms of access, there is a wide variability in the amount of water accessed by the urban poor (without properties), residents with their own houses, hotel owners, and economically well-off people. The distribution also varies with the geospatial locations of the settlements, with peripheral suburbs receiving much less water than the core areas of the town. For example, the households in the core city of Dhulikhel get six hours of water service every day, whereas in semi-periphery households get water for only three hours a day. Further afield, the peripheral communities get water for 15 to $30 \mathrm{~min}$ a day or even on alternate days. People living in the lower elevations and poorer belts—away from the water supply station—complain 
that they have not been treated fairly in water distribution (Summary of interviews taken between 2014 and 2018). Newly settling residents also complain about high installation costs of taps in their houses. A recent study found that the Rosi stream watershed area is experiencing diminished precipitation pattern and stream flow [32], which can drive further water insecurity in the region.

Like many traditional small towns in the lower Himalayas, Dhulikhel settlements are clustered around the ridge of a mountain, but unlike many others, the city does not have an associated higher elevation mountain watershed to supply spring water. However, to the south-west of the city, there are two higher elevation mountain watersheds that supply water flow in excess of the demand of the immediate communities. Recognizing this opportunity, thirty years ago, the town tapped water from Rosi stream $14 \mathrm{~km}$ away, with support from German aid (See Figure 5).

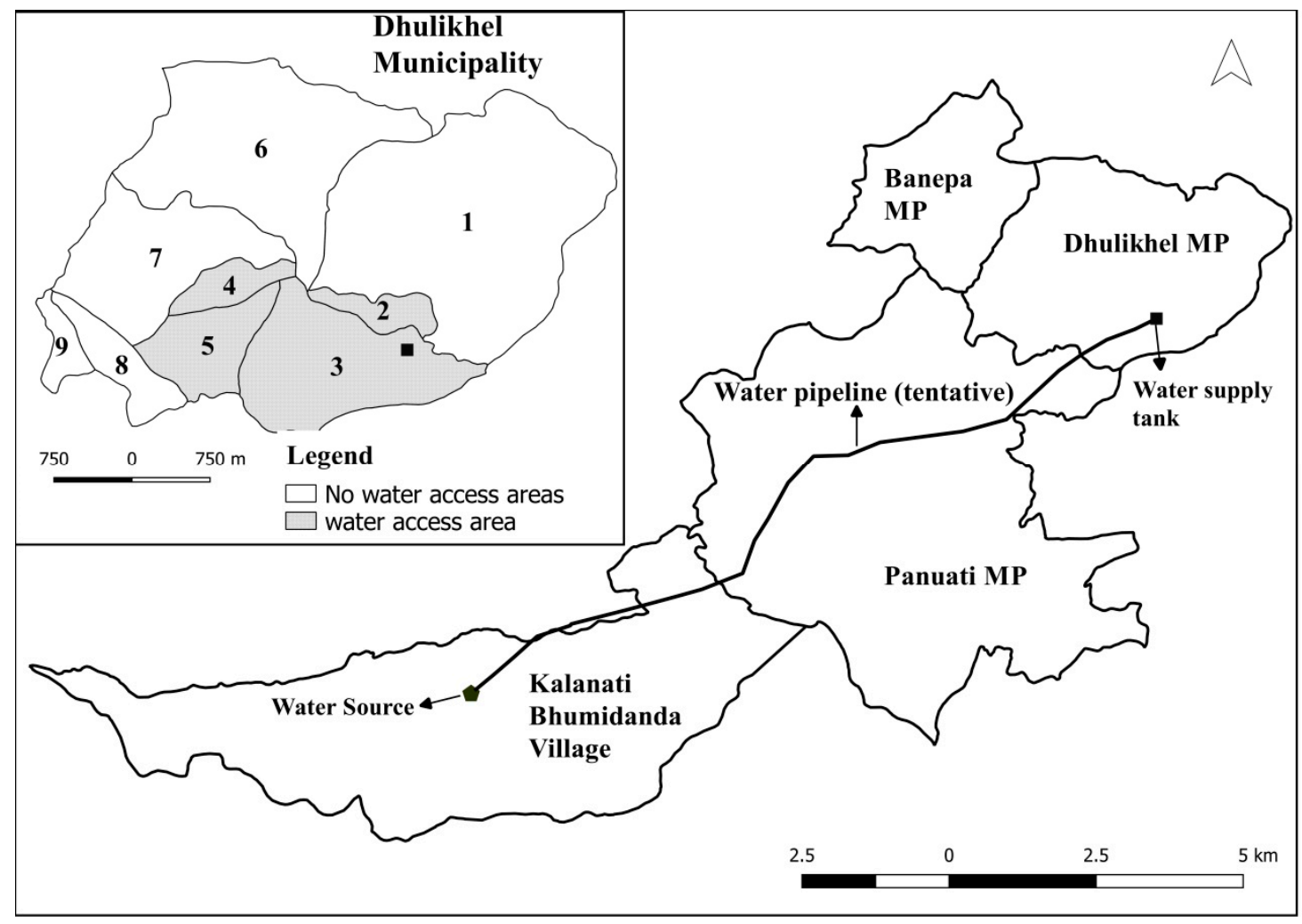

Figure 5. Map showing Rosi river water intakes, pipe routes, Dhulikhel reservoir, and boundaries of water supply system.

In addition, the town also uses other sources of water such as small springs and groundwater though at much smaller scale. Since the water was first brought to Dhulikhel from Rosi stream, frequent conflicts have occurred between Dhulikhel Drinking Water User Committee (DDWUC) and the upstream rural communities. During our field work, upstream people were found to be dissatisfied by their water being tapped away by downstream towns, mainly Dhulikhel. Such local political tensions have been partly instigated by a concurrent national level policy transition that favors local and indigenous control of natural resources, thereby prompting local communities to assert claims over water and other natural resources. To compensate legitimate claims of upstream communities, Dhulikhel residents agreed to make financial payments to upstream people (equivalent to US\$ 9000 per year from 2010) [33], which reflects the idea of Payment of Ecosystem Services (PES). However, upstream people consider that the payment is not enough to cover the losses resulting from the diversion of water from their areas. We saw the previous agreements signed by the upstream Bhumidanda Village and Dhulikhel are now being challenged. In the autumn of 2017, a poster in the source village read 'beware of water sellers', clearly expressing dissent to their leaders who agreed to 
'sell' Rosi stream water to Dhulikhel. Dhulikhel city leaders also expressed their disassociation over not using the money for conserving water sources, but used to build roads and infrastructures possibly damaging the water sources.

Two water governance issues have become crucial. First, the tradeoffs that exist between two of the most common competing uses of water-drinking versus commercial use - is at the heart of the upstream-downstream water conflict. Dhulikhel water leaders have always argued that they needed water for drinking, and that Nepal's national water law also privileges drinking over other uses, such as irrigation. In this context, the distribution issue has become complicated given the unresolved trade-off between household consumption and commercial use. Second, the modality of water governance is a matter of high importance. Dhulikhel's water governance is neither state-managed nor private sector led. It is primarily a community-managed system, closely supported by the central and local governments. It has the potential to supply water at a reasonable price, compared to private sector management, and also more efficiently than the government agency. But as one community leader remarked: "we have to recover all costs of the water supply system from the tariffs, discussion of which is extremely contested in the annual user assembly". Another prominent concern of the existing DDWUC officials is the establishment of new water governing institution, known as Kavre Valley Water Board, which is being considered under the ADB supported project. The DDWUC officials told us that the city residents are wary of ADB's proposal to integrate community-based water supply systems of Dhulikhel with those of the two other neighboring cities, all of which depend on the water from Rosi River.

A key lesson from Dhulikhel's water struggle is that a city can take bold actions towards securing water if communities are engaged well in planning and management. However, the community led initiative is experiencing its limits, and there is a need for wide water planning and collaborative governance to ensure smooth cooperation with upstream communities. The sustainable water security of Dhulikhel needs a comprehensive plan, which can address downstream water scarcity as well as socio-economic, development, and watershed conservation challenges of the upstream population. A fair deal needs to be agreed with the upstream communities for the water which Dhulikhel needs, in order to sustain its growth and development. Similarly, linking science, research, civic sense, and political reasoning is required to achieve a fair institutional arrangement for water supply management. Another lesson is that Dhulikhel has not adequately explored alternatives to the upstream water source. There are options, such as rainwater harvesting and local residents also see hope in the numerous small spring sources at different locations in the township [34]. There is also an opportunity for developing climate adaptive recharge ponds which has been piloted successfully in recent times and the Municipality has plans to upscale it. Commercial water users could also look at ways of recycling the waste-water. Kathmandu University has already demonstrated the feasibility of this but it needs to be further explored.

\section{Haldwani: Limited Supply, Increasing Demand, and Complex Water Institutions}

Haldwani a is a major trading center in the Indian State of Uttarakhand. Like Dharan in Nepal, it is located at the foot of the Himalayas. The population as per 2011 census is 156,078 [35] and is governed by the Municipal Corporation as per the State's governance structure. The city's water supply rests on three main sources. First, the Gaula river, which originates in the lower Himalaya and depends upon springs to maintain its flow. Second, the Sheetlahat spring, about $3 \mathrm{~km}$ upstream in the lower Himalayas. Uttarakhand Pay Jal Nigam (UPJN) and Jal Sasthan are the two public institutions engaged in water supply management in Haldwani. Over the past decade, the city has witnessed large in-migration from upper reaches of Kumaon and expanded rapidly as a city with greater number of low socio-economic groups settling in southern suburbs. The pressure of urbanization and population has increased the demand of water manifolds, with acute water shortages in the summer months. There is also a reduction in precipitation over the years in Kumaon region leading to depletion of springs. 
While the majority of the population faces water scarcity, marginal populations are the worst affected because of their limited means and high dependency on municipal water supplies.

Despite efforts by the state government, there has been a continuous shortage of water throughout the year. Haldwani should be able to provide 135 to 150 LPCD, which is India's prescribed standard for cities with the population size of 100,000 or above. However, the water availability per capita is merely 85 LPCD which goes further down to 50 LPCD during the dry season. The drinking water available for the city per day is approximately 27 MLD, while the storage capacity is only 18 MLD, so a shortfall of 9 MLD is observed and the deficit becomes more severe during summer when the springs dry up. On the supply side, Gaula Canal provides 15.8 MLD water to the city, an additional 3.5 MLD is added by Sheetlahat spring, and by tapping water from Gaula from the higher reaches of the catchment. Excessive groundwater extraction takes place in the city through private bore-wells, which add another 17.28 MLD water to the city (See Figure 6). Large number of borewells operate without permission from the government, causing ground water depletion. The river experiences low lean season flow as a result of springs drying up, forest degradation, unsustainable mining activities, and changing weather patterns.

Being an old city, the water infrastructure is about 50-60 years old and outmoded. Leakages from pipelines account for $20 \%$ of the supply. Sewage water often enters these pipes through the leakages. The Gaula river and water from other sources are highly contaminated. UPJN states that regular analysis of water quality is being conducted and the test results of ground and surface water are well within permissible limits of acceptability and does not require any specific treatment except chlorination. However, a cross-sectional study conducted to assess the bacteriological quality of water in Haldwani showed contradictory results. All water samples $(n=15)$ from different sites of the Gaula river were found to be highly contaminated. Out of 24 water treatment plant samples, four were found unsatisfactory, while more than half $(51.6 \%)$ of its supplies to water taps were polluted. From tube wells and their water taps, $88.8 \%$, and $60 \%$ samples were found safe for drinking, respectively. Bacterial contamination of water treatment plants and their supplies indicate significant disparities in the efficiency of water treatment processes. Contamination of water taps of tube wells suggests leakage of pipes.

The fundamental reasons for the water scarcity in Haldwani, include (based on stakeholders' views from water forum meetings): (1) Low storage capacity of the treatment plant; (2) 60-year old pipelines, water infrastructures and high leakage; (3) faulty distribution system; (4) water contamination; (5) growth in demand in high-density areas within which the existing diameters of pipeline cannot cope; and (6) limited institutional capacity of the local government. Despite the surplus water available for the city during monsoon season, the city's water supply agencies have not been able to harvest and store the water to meet the growing demand. The minimum availability of raw water from Gaula river is $87.26 \mathrm{MLD}$. Sheetlahat spring is gradually depleting. The groundwater is being extracted by tube wells to provide $56 \%$ of the current total water production. There are 13 working tube wells with total rated discharge of 17.28 MLD. UPJL is installing additional four tube wells with total rated discharge of 5.32 MLD.

Haldwani's water security struggles reveal several insights into how a rapidly expanding urban community copes with limited supply of surface water. First, it lacks strategies and mechanisms to monitor ground water and overall quality of water supplied in the city. Situated at the foot of the Siwaliks, on the porous surface of boulders and gravels called the bhabar zone, Haldwani struggles to retain rainwater and then supply it in the dry season. There is a need to improve storage capacity to store the excess water during the wet season. A closer monitoring of surface and sub-surface water flow could better inform the city's water planning. Second, the city is exploring multiple options for improving water use practices. These options include: Rain water harvesting, and re-use and re-cycling system in the government schools and other institutions. Third, water related social exclusion and inequities continue to go unattended: (i) The slum areas of Haldwani are in dire need to clean water and sanitation systems; (ii) lower social strata households are not sufficiently covered by municipal 
water supply system; and (iii) gender based disparity in water related practices are also severe as women play a major role in household water management, while children are the worst affected by water-borne diseases in comparison to adults.

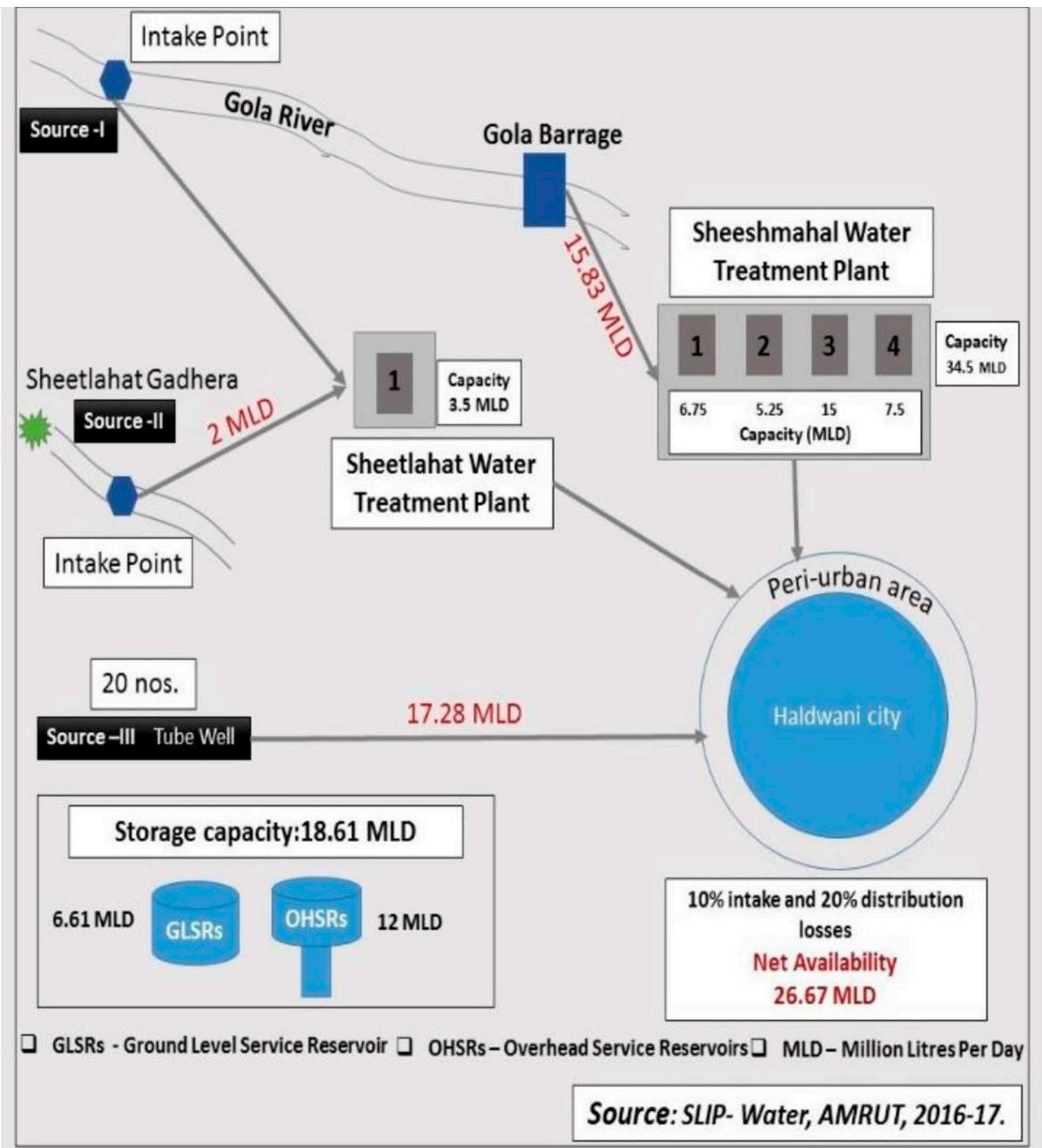

Figure 6. Water source, storage and distribution map of Haldwani.

\section{Mussoorie: Pumping Water Upstream for Floating Tourist Populations}

Mussoorie is a hilltop town, located in Dehradun district of Western Himalaya in the state of Uttarakhand, India. It is also referred as the 'Queen of Hills'. Situated at an altitude of 2005 m, it is spread over an area of approximately 64.8 square kilometers. The town is one of the most popular tourist destinations in Northern India. The population of Mussoorie is 33,657, with the urban population growth rate of $14.8 \%$ [35]. The town was set up in 1825 by the British as a hill station, and ever since, its population has grown consistently, due to the attraction of temperate destination north of a hot and humid city of Dehradun. The city attracts a large number of domestic and international tourists every 
year, and tourism constitutes a large part of the water demand equation in the city. During the peak season (May-July) the number of tourists often exceeds the population of the town, and the population density can go as high as 1000 people per square kilometers. In the lean season, the town experiences "weekend tourists", with arrivals from the States of Uttar Pradesh, Delhi, Haryana, and Punjab.

There are as many as 23 springs and brooklets in Mussoorie region and these springs/brooklets are used for supplying water to the resident population, tourists, and businesses in the town. Located on the top of the hills means that it does not have the advantage of accessing water from mountain springs through gravity, which is the reason why 23 of its current water supply units (See Figure 7) actively pump water from the lower level springs and streams located on different sides of the hills. The public water supply and demand management system has not been able to match needs, as only Our household survey results show that $25 \%$ of residents inform that they obtain just enough water from the public distribution system, while the remainder of populations do not get it needed amount of water.

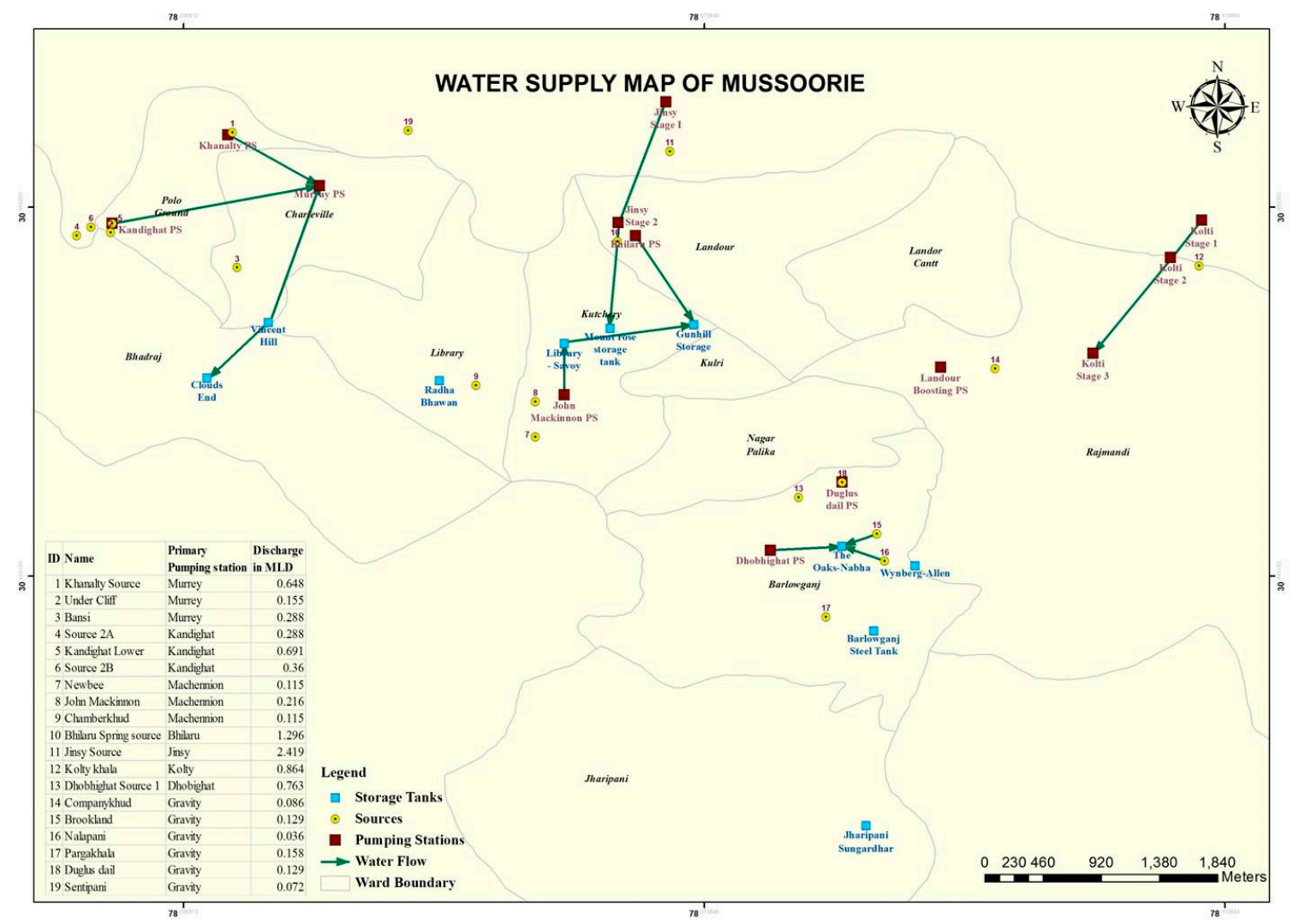

Figure 7. Map showing water pumping points, storage and distribution area.

Mussoorie city is divided into eleven municipal wards and water supply system is the responsibility of Uttarakhand Pay Jal sansthan (UPJS) and UPJN as is the case of Haldwani. Since the early 1990's, tourism infrastructure has increased consistently. The total number of registered hotels, dharamashalas, paying guesthouses has increased from 140 in 1998 to 186 in 2011, while the increasing trend continues. Shops and restaurants have proliferated in the last decade to cater to the needs of the growing tourist population. Nearly $40 \%$ of the water need is supplied by informally operating water tankers, which collect contaminated water from "Dhobhighat" (area designated for washing clothes of domestic, institutional and tourist population of Mussoorie few kilometers below the city). The city's water related risk is further linked to its seismically active location. The settlements are aligned on narrow roads running across the steep slopes, which host old houses with water tanks mounted on the side veranda or rooftop, a practice that escalates safety risks, given the location of the town in India's high seismic risk zone (Zone IV) in western Himalaya. For the urban poor, homeless and temporary migrant 
workers, water mostly comes from the public tap, while the private tap access remains the preserve of the better off families, hotel owners, schools and other businesses. Of these, schools constitute a large part of the water demand network as approximately 10 residential schools from British colonial times operate in the town.

Despite being a major tourist destination, attention to water management is still limited. The efforts are focused on installing pumps to uplift water from the sources around the town. Water services form private tankers are rapidly growing without much regulation and strategic planning. The colonial period infrastructure suggests that rainwater harvesting was a historical practice, but the this has been completely discarded, despite the city bylaws making it a mandatory requirement. Only one hotel has adopted this, and small number of conservation-oriented households have installed rainwater harvesting units, making them self-reliant on water supply. Some schools are also making institutional level attempts to install rainwater harvesting systems.

Mussoorie teaches three important lessons about the water security struggle in the Himalayas. First, when the public system fails, private system (formal/informal) fills the gap, as there is always a willingness to pay for vital services like water, although such solutions are not sustainable. Second, public taps and open access water systems can offer easier access to the poor and disadvantaged groups, alongside the installation of private tap systems if maintained by a progressive tariff system. Third, water management institutions need to take a more adaptive and planned approach to monitor and respond to emerging trends in demand and supply of water, including the potential impact of climate change on the springs in which the town relies on water.

\section{Discussion: Key Themes and Issues in Tackling Urban Water Insecurity}

The five cities' struggle for water security highlight at least six key themes and issues, which resonate, not only in the Himalayan region, but also more broadly across the developing world. First, there is an absence of a strategic approach to assessing water insecurity in relation to imminent drivers including urbanization and climate change, and instead there exists a tendency to take a piece meal and reactive approach to tackle water scarcity. Likewise, there is hardly any attempt to integrate and operationalize the concept of water security at the city level in the Himalayan region, despite the concept's rise to prominence in the global academic and policy literature [11]. Operationalizing water security concept in specific city contexts is important, as it not only facilitates planning of aggregate water demand and supply, but also supports negotiations in water allocations among communities and groups [12]. All the five cities are facing water shortage and much of the planning and water management practices center around the 'supply' of water, with little or no attention to the projected drivers of future supply of water, not to mention the challenges on access and equity. Even when these issues are recognized to some extent, these are not adequately articulated in the water planning and governance discussions. The neglect of water challenge in India's water policy has been highlighted recently in the wider media as well.

Although, water research and development activities have proliferated in recent years, we found that water planning and governance practices remain uninformed by such research especially on climate change and urbanization [22]. Studies of climate change impacts indicate changes in monsoon patterns and heavy rain concentrations [36], while yearly rainfall has not changed significantly [37]. In the context of changing climate and weather patterns, building knowledge on local hydrological and meteorological databases, and changing patterns of water demands is critically important. All of the five cities we studied have a number of water quality related issues unaddressed in the upstream water source areas (such as livestock and human waste injected into the water source in Dharan, and Gaula river, Haldwani). The existing water institutions have limited capability for taking a strategic approach required to understand and tackle the multi-faceted drivers of growing water insecurity challenge (see Figure 8 for a summary of drivers and cities' responses). 


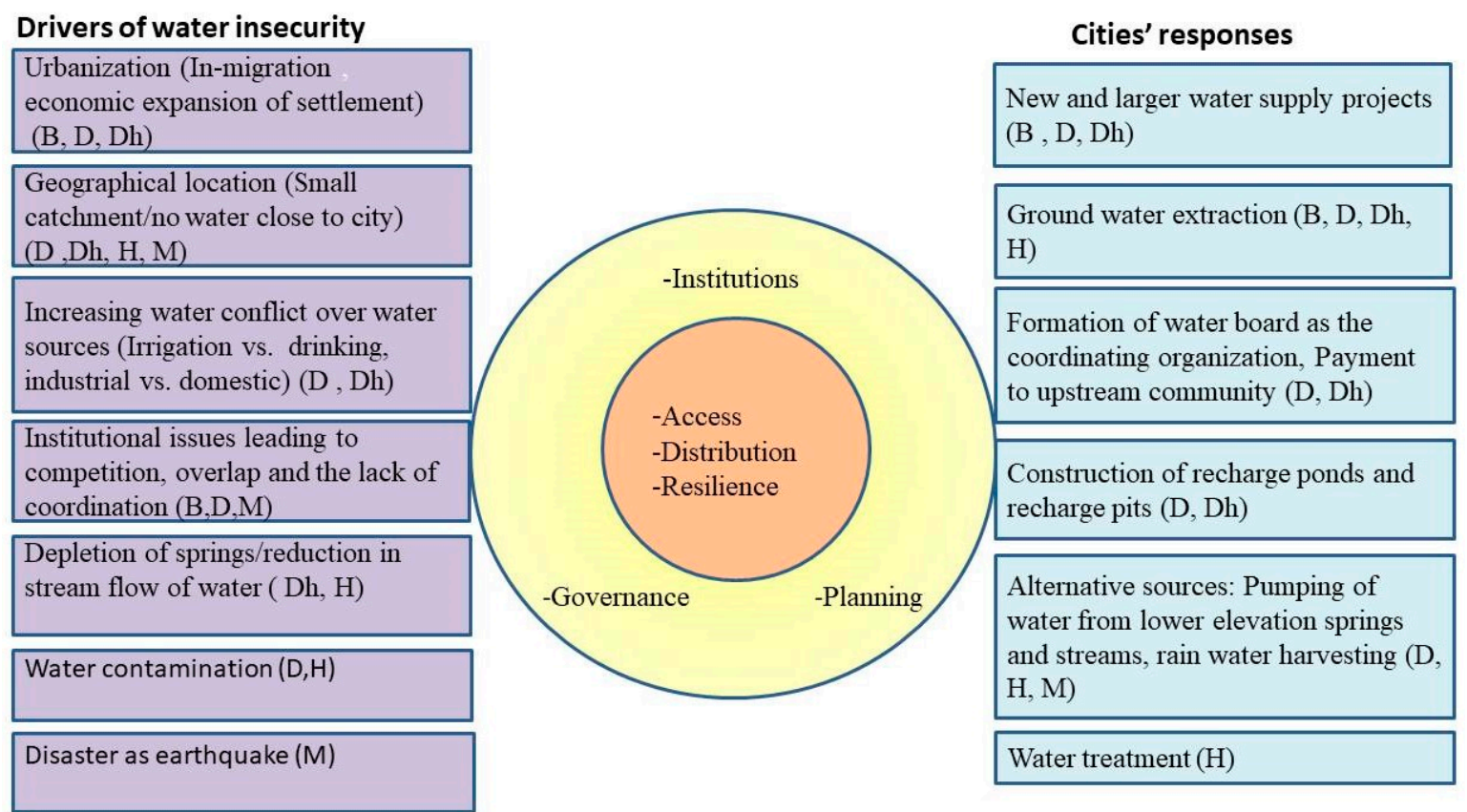

*B-Bidur, D-Dharan, Dh-Dhulikhel, H-Haldwani, $M$ - Mussoorie

Figure 8. A synthesis of drivers of water insecurity and cities' responses in the five case study cities.

Second, both Nepal and India have many institutions in water governance with a long legacy and path dependence that are not fit to deliver new roles in the changing context. As new challenges emerge from the rising population, urbanization, and climate change, some of the institutions have become obsolete, although there have been some attempts to change them in the light of these new challenges (such as decentralization of water management responsibility to the municipality) [22]. However, such institutional reform is hardly informed by an understanding of the scale and nature of the water insecurity challenges the cities are facing, and at times, these institutions act as barriers to water security rather than contributing to it. For example, multiple and conflicting institutions, such as Jal Nigam, Jal Sansthan and others in India's Uttarakhand have been created, leading to fragmentation of water management systems with limited coordination. Too often, the poor and women have lost access to water, due to failures in democratic politics and participatory governance. We did not find sustainable water tariff systems that could enable water institutions to continuously engage in maintenance and upgrade system to expand water service coverage of quantity and quality of water. In all city case studies we found the core of the city has greater access to water resources inequitably compared to peripheral areas. Not surprisingly, institutions have also shaped water access across gender and social class. For example, in both Nepal and India, the entitlements of land and house play significant roles for households to access water and represent them in water related decision-making forums. The land ownership certificate and house ownership certificate are found to be the most important legal preconditions for households to have access to formal water supply system, which keeps the most vulnerable and poor out of the reach of formal water services. In Mumbai, India studies showed that social pressure is exercised by land-less groups to claim water, which is officially available to formal settlements with registered land and property [38]. Yet others argue that despite continuous struggles by marginal groups for equitable water access, they have not been able to push any institutional changes to create just urban spaces [39]. While women are key water managers at the household level, men often make water-related decisions in public domains.

Third, addressing water conflicts between rural upstream and urban downstream communities is a key aspect of urban water insecurity in the Himalayas. As downstream urban areas expand and commercial agriculture potential in the rural upstream areas also grows, water becomes an even more 
contested resource in the region [20]. In some cases, such as Dhulikhel, there has been a history of negotiation and putting in place a mechanism of compensation to the upstream communities [40]. However, under rapid economic and political changes, the negotiated arrangements have not endured, and repeated negotiations and conflict management have become mandatory in the governance of water. In the future, managing water conflicts becomes even more important and should be carried out by water governance agencies. However, the water governance systems in both Nepal and India do not appear to be actively foreseeing water conflicts, let alone instituting arrangements for mediating water conflicts. Integrated water management has been advocated as a possible solution to forge cooperation among water actors across different subsectors, yet the effectiveness of such approaches in practice is not well-established [41].

Fourth, there is lack of clarity on policy direction in both countries on how limited and actually available water can be mobilized in an equitable and sustainable way. In India, as per the Government of India Act (1935), States have exclusive power to regulate water supplies, irrigation and canals, drainage and embankments, water storage, hydropower, and fisheries [42]. Yet, India has a number of federal level water policies and institutional structures to regulate various aspects of water governance. However, it still lacks an umbrella framework to regulate freshwater in all its dimensions [43]. In the State of Uttarakhand, a water law framework came into place through the Kumaon and Garhwal Water (Collection Retention and Distribution) Act 1975. This Act was passed to regulate and control, for public interest, the water resources in the mountain tracts of the Kumaon and Garhwal divisions, and for this purpose "empowered the State government to regulate and control, by rules under the Act, the collection, retention, and distribution of water and water resources." This Act empowers the State government "to demarcate areas for protection of water resources and to declare the same as protected area", which specifically prohibits cutting of "trees, bushes, shrubs, or burn dried grass in any protected area without the permission in writing of the Sub-Divisional Officer." Clearly, the conservation emphasis is not matched by arrangements for distribution and access rights to ensure equity and minimize potential water conflicts.

In Nepal, there are also multiple laws, rules, and policies, which create overlapping and contradictory provisions in regulating the water sector. Most of these statutory documents have created too many institutions across different levels, without ensuring effective coordination and collaborative mechanisms. While municipalities have been authorized to conserve, manage, and use water within their jurisdictions, the Water Supply Management Board Act 2006 has provisioned another autonomous and corporate body to manage the service system within one or among multiple municipalities. While the ultimate ownership of water is vested in the state mechanism (Article 3 of Water Resource Act 1992 clearly mentioned that-the ownership of the water resources available in Nepal shall be vested in Nepal), actual practices of defining water rights are undertaken by taking references to conflicting regulatory provisions found in different legislative and policy instruments. As a result, the conflicting provisions of water rights and water use priority have led to contestations over the use and allocation of water. Contestations between drinking and irrigation users, between upstream and downstream users, and between subsistence and commercial users have become increasingly common in recent years. For instance-local communities in Bhumedanda village of Kavre district Nepal claimed that the water from Rosi river, which flows along their settlement and which has been used by them for a long time, must remain their exclusive right. On the contrary, the people from Dhulikhel municipality who are located farther away from the river, but have license to use water from Rosi river also claimed that they must have access to use water.

Finally, limited attention has been paid to promote technological innovation in water use and management. Technology use is crucial in supporting sustainable water management strategies and practices to meet the increasing demands for water in the era of anthropogenic climate change which leads to a gradual decline of water supply system [44]. Technological solutions are a critical part of the water security agenda - especially in the mountainous region where settlements concentrate on higher elevations, while water sources are located at lower elevations. Debate about technological 
options center around creating infrastructure to tap water from distant sources versus capturing and recycling storm waters [45]. The case study cities could embark on two technological pathways for making cities water secure. The first is prioritizing low cost technologies in line with nature-based solutions-such as source conservation, rain-water harvesting, climate adaptive recharge ponds and pits, and generating awareness for behavioral changes for efficient use of water. This type of microscale landscape-based practices is drawing the attention of the local institutions [46], primarily due to the low cost involved [47]. The second pathway is techno-engineering efforts for addressing water insecurity. They can be of two types; one is meso level water infrastructure development. For example, tapping water from perennial rivers and diverting the water flow to urban centers, which may spark conflicts between peoples living in the upstream and downstream, and could very likely affect the biodiversity and agricultural practices of riparian people along the natural path of the rivers. This has too often been the case because this type of project is done without creating deliberative platforms for engagement between water practitioners and community members [48]. The other is to develop and install water efficient technologies in bathrooms, toilets, and agricultural practices. This also includes increases in water storage capacity, fixing the leakages, reduce leakage, or non-revenue water. The slow progress on technological improvement in the case study cities show that this requires enabling multi-scale governance and policy support, and so cannot be left as the sole responsibility of local municipal governments.

\section{Conclusions}

The urbanizing regions of the lower Himalaya are facing acute water insecurity despite being situated below the world's water tower. In this paper, we have presented stories of struggle for water security in a sample of five towns of Nepal and India, using the data gathered from five years of field research between 2014 and 2018. The study reveals that, although there are variations, there are also some striking parallels across the five case study cities. A key finding to be noted is that the physical availability of water does not lead to water security; four of the five towns are struggling to develop well-performing local institutions to manage the supply of water. None of the cities have a robust system of water planning and governance to ensure ways to secure water in the context of rapid urbanization and climate change. The lack of water security planning and proactive monitoring of climate impacts are absent from all cases, which can undermine the prospect of water security. Clearly, the regional and international discourses on water security and climate resilience have not yet been translated into local and city level plans and activities. There is a lack of framework and system of support to enable local level decisions makers to understand and internalize water security ideas, in practice. In the absence of coordinated water planning on the part of the state, a complex mix of government, community, and private systems of water supply have emerged in the Himalayan towns across both Nepal and India. Moreover, water is being turned into a commercial commodity to be bottled and sold, and the traditional values of water as a natural gift and privilege to be respected and revered, has almost disappeared. The current trends and efforts to catalyze reforms, such as the Asian Development Bank supported institutional upscaling projects also lack careful consideration of socio-technical, cultural, climate change, and environmental contexts and issues, as these are narrowly focused on securing economies of scale by physical integration and institutional upscaling of the water supply systems. The Himalayan urban region is thus in need of fresh thinking and an approach to transformative and sustainable water management that puts long-term water security at the core, informed by research into socio-technical transitions and multi-level governance.

Author Contributions: All the co-authors contributed to conceptualisation of the research and conducted field investigation. H.O. led the drafting of the paper while other co-authors contributed specific case study reports. K.R.N. coordinated communication among co-authors and contributed to data analysis as well. All authors have read and agreed to the published version of the manuscript. 
Funding: The authors gratefully acknowledge International Development and Research Centre (IDRC) Canada for support of this study through its Cities and Climate Change initiative for funding support for the period of 2016 to 2019 and Ecosystem service and Poverty Alleviation Program UK for 2014-2016.

Acknowledgments: The authors gratefully acknowledge the contributions made by Kamal Devkota and Tikeshwori Joshi and Suchita Shrestha of SIAS and Anvita Pandey, Riyan Habeeb and Manya Singh of CEDAR during data collection. The authors also acknowledge UK Ecosystem Services and Poverty Alleviation (ESPA) supported project "The political economy of water Security, ecosystem services and livelihoods in the Western Himalayas". We have benefitted from the collaboration with Bhaskar Vira and Eszter Krasznai Kovács, Cambridge University. The follow up study for this paper was supported by Canadian International Development Research Center funded project "Climate Adaptive Water Management Plans for Cities in South Asia". None of the organizations credited here, or those with which the co-authors are associated, have any responsibilities or obligations related to the content of the paper, which is solely the work of the co-authors.

Conflicts of Interest: The authors declare no conflict of interest.

\section{References}

1. Kidd, C.; Huffman, G. Global Precipitation Measurement. Meteorol. Appl. 2011, 18, 334-353. [CrossRef]

2. Shrestha, A.B.; Agrawal, N.K.; Alfthan, B.; Bajracharya, S.R.; Maréchal, J.; van Oort, B. The Himalayan Climate and Water Atlas: Impact of Climate Change on Water Resources in Five of Asia's Major River Basins; International Centre for Integrated Mountain Development (ICIMOD), GRID-Arendal and CICERO: Kathmandu, Nepal, 2015.

3. Bajracharya, S.R.; Maharjan, S.B.; Shrestha, F.; Guo, W.; Liu, S.; Immerzeel, W.; Shrestha, B. The glaciers of the Hindu Kush Himalayas: Current status and observed changes from the 1980s to 2010. Int. J. Water Resour. Dev. 2015, 31, 161-173. [CrossRef]

4. Bharti, N.; Khandekar, N.; Sengupta, P.; Bhadwal, S.; Kochhar, I. Dynamics of urban water supply management of two Himalayan towns in India. Water Policy 2019. [CrossRef]

5. Mukherji, A.; Molden, D.; Nepal, S.; Rasul, G.; Wagnon, P. Himalayan waters at the crossroads: Issues and challenges. Int. J. Water Resour. Dev. 2015, 31, 151-160. [CrossRef]

6. Flörke, M.; Schneider, C.; McDonald, R.I. Water competition between cities and agriculture driven by climate change and urban growth. Nat. Sustain. 2018, 1, 51-58. [CrossRef]

7. Ishtiaque, A.; Shrestha, M.; Chhetri, N. Rapid urban growth in the Kathmandu Valley, Nepal: Monitoring land use land cover dynamics of a himalayan city with landsat imageries. Environments 2017, 4, 72. [CrossRef]

8. UNDESA. World Urbanization Prospects: The 2014 Revision; United Nations Department of Economics and Social Affairs, Population Division: New York, NY, USA, 2014.

9. Tiwari, P.C.; Joshi, B. Environmental Changes and Their Impact on Rural Water, Food, Livelihood, and Health Security in Kumaon Himalaya. Int. J. Urban Reg. Stud. Contemp. India 2014, 1, 1-12.

10. Magsig, B.-O. International Water Law and the Quest for Common Security, 1st ed.; Routledge: London, UK, 2015. [CrossRef]

11. Cook, C.; Bakker, K. Water security: Debating an emerging paradigm. Glob. Environ. Chang. 2012, 22, 94-102. [CrossRef]

12. Allan, J.V.; Kenway, S.J.; Head, B.W. Urban water security-what does it mean? Urban Water J. 2018, 15, 899-910. [CrossRef]

13. McDonald, R.I.; Weber, K.; Padowski, J.; Flörke, M.; Schneider, C.; Green, P.A.; Gleeson, T.; Eckman, S.; Lehner, B.; Balk, D. Water on an urban planet: Urbanization and the reach of urban water infrastructure. Glob. Environ. Chang. 2014, 27, 96-105. [CrossRef]

14. GWP. Towards Water Security: A Framework for Action Foreword; GWP: Stockhom, Sweden, 2000.

15. van Beek, E.; Arriens, W.L. Water Security: Putting the Concept into Practice; Global Water Partnership Stockholm: Stockholm, Sweden, 2014.

16. Ait Kadi, M.; Arriens, W.L. Increasing Water Security: A Development Imperative. GWP Perspective Paper; Global Water Partnership: Stockholm, Sweden, 2012.

17. Chenoweth, J.; Malcolm, R.; Kaime, T.; Pedley, S. Household water security and the human right to water and sanitation. Water Secur. Princ. Perspect. Pract. 2013, 307-318.

18. Ainuson, K.G. Urban Water Politics and Water Security in Disadvantaged Urban Communities in Ghana. Afr. Stud. Q. 2010, 11, 59. 
19. Fuenfschilling, L.; Truffer, B. The interplay of institutions, actors and technologies in socio-technical systems-An analysis of transformations in the Australian urban water sector. Technol. Forecast. Soc. Chang. 2016, 103, 298-312. [CrossRef]

20. Kovács, E.K.; Ojha, H.; Neupane, K.R.; Niven, T.; Agarwal, C.; Chauhan, D.; Dahal, N.; Devkota, K.; Guleria, V.; Joshi, T.; et al. A Political Ecology of Water and Small-Town Urbanisation across the Lower Himalayas. Geoforum 2019, 107, 88-98. [CrossRef]

21. Singh, V.; Pandey, A. Urban water resilience in Hindu Kush Himalaya: Issues, challenges and way forward. Water Policy 2019. [CrossRef]

22. Pandey, C.L.; Maskey, G.; Devkota, K.; Ojha, H. Investigating the Institutional Landscape for Urban Water Security in Nepal. Sustain. J. Rec. 2019, 12, 173-181. [CrossRef]

23. Pandey, C.L.; Bajracharya, R.M. Climate Adaptive Water Management Practices in Small and Midsized Cities of Nepal: Case Studies of Dharan and Dhulikhel. Sustain. J. Rec. 2017, 10, 300-307. [CrossRef]

24. NUDS. National Urban Development Strategy 2017; Government of Nepal: Kathmandu, Nepal, 2017.

25. Government of India. Uttarakhand Development Report; Government of India: New Delhi, India, 2009.

26. Shah, M. Urban Water Systems in India: A Way Forward; Working Paper; Indian Council For Research on International Economic Relations: New Delhi, India, 2016.

27. Dahal, N. Struggle of a Small Town for Water; The Spotlight: Kathmandu, Nepal, 2014.

28. Devkota, K.; Khatri, D.; Neupane, K.R. Water Conflicts In Urbanizing Regions In The Himalaya: Case Studies From Dhulikhel And Bidur In Nepal. Southasia Inst. Adv. Stud. 2018, 5, 1-25.

29. Third Small Towns Water Supply and Sanitation Sector Project. Semi-Annual Environmental Monitoring Report. 2017. Available online: https://www.adb.org/sites/default/files/project-documents/35173/35173-013emr-en_0.pdf (accessed on 20 December 2019).

30. Paudel, D. Study Report of Economic Valuation of Watershed Scheme for Sardu Watershed Conservation; IUCN: Kathmandu, Nepal, 2010.

31. CBS. National Population and Housing Census 2011 (National Report); CBS: Kathmandu, Nepal, 2011.

32. Dahal, N.; Shrestha, U.; Tuitui, A.; Ojha, H.; Dahal, N.; Shrestha, U.B.; Tuitui, A.; Ojha, H.R. Temporal Changes in Precipitation and Temperature and their Implications on the Streamflow of Rosi River, Central Nepal. Climate 2019, 7, 3. [CrossRef]

33. Joshi, T.; Kovacs, E.K.; Neupane, K.R. Incentives For Securing Water In A Himalayan Town: A Case From Dhulikhel, Nepal. Southasia Inst. Adv. Stud. 2019, 6, 1-20.

34. Dahal, N.; Devkota, K.; Neupane, K.R.; Shrestha, S. Can Dhulikhel Offer Role Model to Nepali Hill Towns for a Sustainable Water Supply Management? The Spotlight: Kathmandu, Nepal, 2017.

35. Census of India. Census of India 2011: Provisional Population Totals-India Data Sheet; Government of India: New Delhi, India, 2011.

36. Singh, D.; Tsiang, M.; Rajaratnam, B.; Diffenbaugh, N.S. Observed changes in extreme wet and dry spells during the South Asian summer monsoon season. Nat. Clim. Chang. 2014, 4, 456. [CrossRef]

37. Dimri, A.P.; Dash, S.K. Wintertime Climatic Trends in the Western Himalayas. Clim. Chang. 2012, 111, 775-800. [CrossRef]

38. Anand, N. Pressure: Thepolitechnics of water supply in Mumbai. Cult. Anthropol. 2011, 26, 542-564. [CrossRef]

39. Roy, D. Negotiating marginalities: Right to water in Delhi. Urban Water J. 2013, 10, 97-104. [CrossRef]

40. Devkota, K.; Neupane, K.R. Water Governance In Rapidly Urbanising Small Town: A Case Of Dhulikhel In Nepal. J. Water Secur. 2018, 4. [CrossRef]

41. Clement, F.; Suhardiman, D.; Bharati, L. IWRM Discourses, Institutional Holy Grail and Water Justice in Nepal. Water Altern. 2017, 870-887.

42. Cullet, P. The Sardar Sarovar Dam Project: Selected Documents; Ashgate Publishing, Ltd.: Farnham, UK, 2007.

43. Cullet, P. Is water policy the new water law? Rethinking the place of law in water sector reforms. Ids Bull. 2012, 43, 69-78. [CrossRef]

44. Depietri, Y.; McPhearson, T. Integrating the Grey, Green, and Blue in Cities: Nature-Based Solutions for Climate Change Adaptation and Risk Reduction. In Nature-Based Solutions to Climate Change Adaptation in Urban Areas: Linkages between Science, Policy and Practice; Kabisch, N., Korn, H., Stadler, J., Bonn, A., Eds.; Springer International Publishing: Cham, Switzerland, 2017; pp. 91-109. [CrossRef] 
45. Porse, E.; Mika, K.B.; Litvak, E.; Manago, K.F.; Hogue, T.S.; Gold, M.; Pataki, D.E.; Pincetl, S. The economic value of local water supplies in Los Angeles. Nat. Sustain. 2018, 1, 289. [CrossRef]

46. Ranzato, M. Landscape elements as a basis for integrated water management. Urban Water J. 2017, 14, 694-703. [CrossRef]

47. Rai, R.K.; Neupane, K.R.; Bajracharya, R.M.; Dahal, N.; Shrestha, S.; Devkota, K. Economics of climate adaptive water management practices in Nepal. Heliyon 2019, 5, e01668. [CrossRef]

48. Farrelly, M.A.; Brown, R.R. Making the implicit, explicit: Time for renegotiating the urban water supply hydrosocial contract? Urban Water J. 2014, 11, 392-404. [CrossRef]

(C) 2020 by the authors. Licensee MDPI, Basel, Switzerland. This article is an open access article distributed under the terms and conditions of the Creative Commons Attribution (CC BY) license (http://creativecommons.org/licenses/by/4.0/). 